\title{
“OWNSELF CHECK OWNSELF”: THE ROLE OF SINGLISH HUMOR IN THE RISE OF THE OPPOSITION POLITICIAN IN SINGAPORE
}

\author{
VELDA KHOO \\ University of Colorado Boulder
}

The People's Action Party (PAP) have won every election in Singapore since 1959 when the citystate was first granted self-governance. Over the years, its regime has been described as authoritarian by political observers (Rodan 2004; Tan 2012), the subjugation of the media a commonly brought-up example of the party's ability to shut down contrasting political views (Seow,1998). With media laws that dictate the freedom of the press and protect the PAP's interests, opposition parties have found it difficult to break their stronghold on the nation-state, and there has been no real political contestation in the general elections. Since 2011 however, the PAP, amidst social pressure to "keep up with the times', have cautiously lifted the total ban on online campaigning and as a result, Singapore politics have undergone rapid mediatization. This has led to two major changes in the local political arena. Firstly, the shift in symbiotic relationships between the mainstream media, political organizations and the electorate in Singapore, has encouraged the paralleled rise of "newly competitive" opposition parties able to capitalize on newer, non-traditional spaces of communication to question the ruling legitimacy of the PAP (Ortmann, 2010). In order to brand themselves as alternative voices to an elite PAP, their public performances have appealed to growing populism, and tap on Singlish, an ideologically valuable linguistic resource, to do so. This paper analyzes the creative, patterned use of Singlish, indexically tied to "the common Singaporean" (J. Leimgruber, 2013), by opposition politicians in rallies to humorously attack PAP candidates and ideas. I argue that such linked uses of humor to language allow for opposition politicians to simultaneously position themselves as fellow lay members of the Singaporean community, and reinforce their own political stances through the deriding of the ruling party. Secondly, the rise of social media and alternative new media on the Internet have created an increasingly sophisticated citizenry (cf. Mazzoleni and Schulz, 1999) that exhibit greater degrees of "open political dissent" (Ortmann, 2010) and scrutinize political actors closer than before. This paper tracks online Singlish memes in which Singaporean netizens mock the PAP's 'inauthentic' expressions of Singaporean-ness and legitimize opposition politicians' use of the language. As such, an alternative linguistic marketplace (Bourdieu, 1977) emerges in which Singlish humor is a symbol of populist resistance and solidarity. Through the analysis of these metalinguistic commentaries, I make a case for the commodification of Singlish as an ideological resource through which Singaporeans construct intersubjectivity and discuss how the nation-state is aligned with certain ways of using language.

Keywords: sociocultural linguistics, Singlish, language and identity 


\section{INTRODUCTION}

On 2 September 2015, nine days before the 2015 Singapore General Elections, the Workers' Party (WP), an opposition political party in Singapore, held its first, highly-anticipated election rally of the season. Five years before in the previous General Elections, the WP garnered six parliamentary seats out of the total 87 seats contested, a shock breakthrough in historically "oneparty Singapore", a country which has been ruled since independence by the People's Action Party (PAP). Six seats out of 87 was just under $7 \%$ of all seats up for election: yet this was seen as a groundbreaking feat, considering that this gave the opposition its largest representation in Parliament in the history of the state (Tan 2014). On that evening of 2 September, more than 50,000 people (Cochrane 2015) gathered in an open field to listen to the WP, a number far outnumbering the $1000+$ crowd at the PAP rally on the same night. Aerial photographs of the massive congregation spread quickly online, the most viral being user-generated memes where scenes of the WP crowd were juxtaposed next to pictures of the considerably smaller PAP rally crowd (see Figure 1).

FIGURE 1. GRAPHIC IMAGE FROM SGAG POST ON 2 SEPTEMBER 2017 (SGAG 2015)

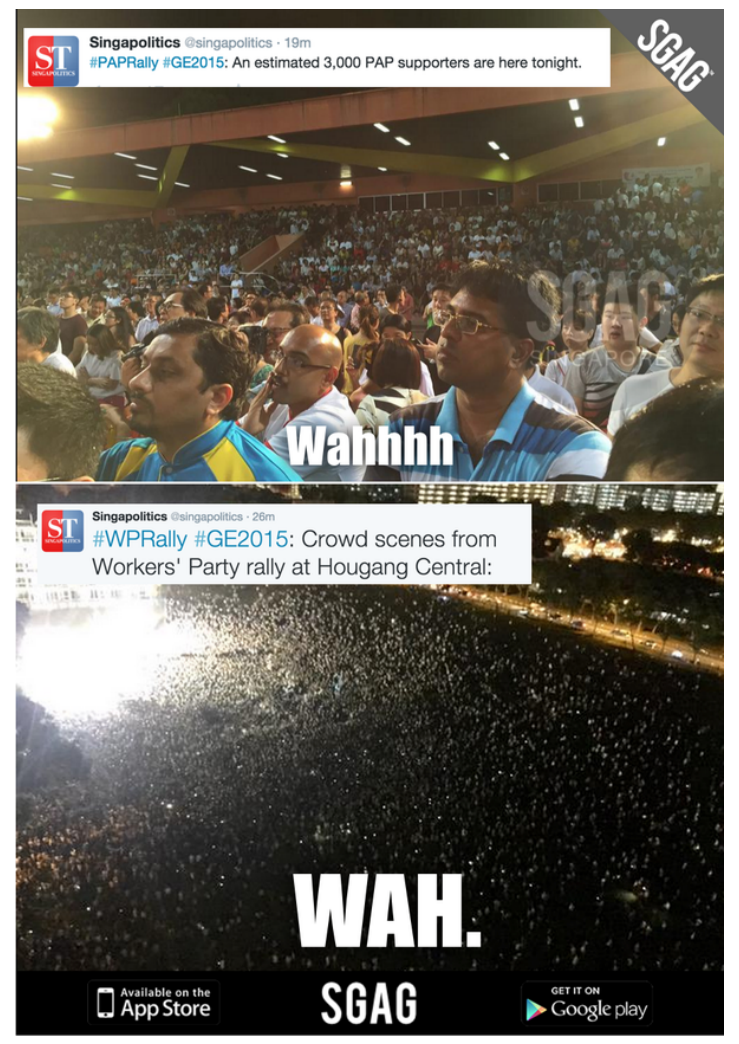


A few speeches into the rally, popular WP Member-of Parliament Pritam Singh gets to the podium and begins his rally speech. He references PAP Emeritus Senior Minister Goh Chok Tong's statement that the PAP did not need opposition parties in parliament to act as checks and balances - "we are our own checks", Goh had declared in an interview just a week ago (Philomin 2015). Singh denounces this together with a rhetorical question in his speech.

Singh: Mr Goh Chok Tong himself, famously said, that the PAP exists in a political system where I quote, they are their own check!

Crowd: ((rally crowd boos))

Singh: Is this the future we want for Singapore or our children in the next fifty years?

Crowd: NO!

Singh: Ownself check ownself!

Crowd: ((laughter and applause))

Singh derides the PAP's claim, implying that performing their own checks and balances is an illogical expectation for the electorate. At this point in the speech, he deviates from what is recognizable as Standard Singapore English, and uses an innovative Singlish expression ${ }^{1}$, the contact vernacular spoken by many Singaporeans. The closest English translation of "ownself check ownself" would be something like "on your own you check yourself". This brief, humorous digression in an otherwise completely serious speech catches the attention of the public. Overnight, Singh's "ownself check ownself" circulates widely across many political websites and social media platforms. The 31-second video segment transcribed above is posted on YouTube with the title "Pritam Singh: PAP Ownself check ownself"; the hashtag \#ownselfcheckownself emerges on Twitter; and gif memes of Singh mouthing “ownself check ownself” proliferate Singaporean web communities. As online users share these memes and videos, they both allude to the hilarity of “ownself check ownself" and declare a lack of support for the PAP's brand of politics. "Ownself check ownself' becomes ENTEXTUALIZED into these newer contexts-of-use (Silverstein 2011) and becomes a part of the online Singaporean lexicon.

\footnotetext{
${ }^{1}$ The hybrid nature of Singlish's makeup (the Singlish lexicon is from among others, English, Mandarin Chinese, Southern Min languages and Malay) and the indefiniteness of whether elements in Singlish are code-switches, borrowings, or part of the language itself have resulted in a "less than straightforward" definition of what Singlish is (Leimgruber 2014); see Hall and Nilep (2015) for a general review of hybrid linguistic processes. I will explore this in more detail further on in the paper.
} 
At this point, I will bring up several observations and points of contention. First, there is the rise of the "newly competitive" opposition party and opposition politician that seems to benefit from non-traditional spaces of communication (Ortmann 2011) as they use humor to attack and question the ruling legitimacy of the PAP. Second, we see the paralleled emergence of a historically politically-repressed public on new platforms of participatory media, an electorate who in the past decades, have had few public channels on which to openly congregate. Third, we can also identify the centrality of language in this picture, and how ideologies surrounding Singlish (and Standard Singapore English) can reflect, and be a means to, shifting relations of power and social inequality in Singapore. By analyzing satirical online discourse of the 2015 General Election, I explore the ENREGISTERMENT (Agha 2005) of Singlish through the ideological linking of language with non-eliteness and political resistance as Singlish-users grapple with questions of linguistic ownership and expertise. As Gal (1989:348) observes, the control of representations of reality not only signals the source of social power, but can also reveal loci of conflict. This paper uncovers the various struggles for symbolic domination through the negotiation of what is linguistically real.

I start with a summary of the history of politics in Singapore, and its current political climate. I examine the legislative changes that have led to the rapid mediatization of Singapore politics in the past decade. The change over time in symbiotic relationships between the mainstream media, political organizations, and the electorate in Singapore can be understood as the foundation for ideological shifts both politically and linguistically. I then look at data from political rally speeches as well as responses and comments from online users on social media platforms, which indicate the emergence of an alternative linguistic marketplace (Bourdieu 1977) in which Singlish, in particular, Singlish humor, become enregistered as a valued symbol of populist resistance. I discuss how these metadiscursive practices constrain what can be and who can use Singlish, as the label becomes an ideological resource through which "anti-PAP" can be a part of the construction of Singaporean-ness. In order to do that, I employ Michael Silverstein's 2003 framework on indexical order, to track how over time, first-order indexicality with correlations to nationality and place can give rise to second-order indexicalities of humor, non-eliteness and political resistance in which a variety gets enregistered as a stabilized set of linguistic features (Johnstone, Andrus \& Danielson 2006). I conclude with thoughts on how the nation-state is aligned with certain ways of 
using language, and how speakers complexify the new spaces that they create as they attempt to effect social change.

\section{MEDIATIZED POLITICS IN SINGAPORE}

An analysis of communicative acts and political discourse in Singapore requires an understanding of the contemporary political climate in the country. As mentioned in the section above, the People's Action Party (PAP) have won every election in Singapore since 1959, when the colony was first granted self-governance from the British, and have held all or most of the seats in every general election since 1968. Throughout the years, the PAP have been the political elite in the country, ruling with virtually no opposition. For many Singaporeans, the PAP name is synonymous with government (Agence France-Presse 2001). Yet a common accusation of the PAP in recent years is their growing disconnect with citizens (Tan 2012), among other things, Singapore's ministers earning the highest ministerial salaries in the world. Under PAP's governance, Singapore's gross domestic product grew steadily from $\$ 400$ (USD) per capita in 1960 to $\$ 61,000$ (USD) in 2013 (Risse 2014). This was a story endorsed by late founding father Lee Kuan Yew as a "third world to first world" miracle (Lee 2012), and Singaporeans easily accepted the PAP's "economic pragmatism" as a common sense "non-ideology" (Chua 1995) that has since percolated through all aspects of Singaporean life. With the ruling PAP associated with long term economic stability and fiscal success, opposition parties are left with a very narrow field in which to articulate alternative visions of leading the nation (Ortmann 2010). As such, political opposition in Singapore have historically been ineffective in having any say in parliament (Mutalib 2002). In 2015, the PAP won almost $70 \%$ of the popular vote, an increase of $9 \%$ from the previous election, and $93 \%$ of the seats in Parliament, ensuring that Singapore would be led by a PAP supermajority for another five years.

\subsection{A CLIMATE OF FEAR}

After the General Election results were announced, Singapore Democratic Party leader Chee Soon Juan, published an opinion piece on his personal website, titled "Fear and our future" (Chee 2015), as he responded to PAP's big win. Chee attributed the loss of opposition votes to voters' "fear[s] at the various stages and aspects of the electoral process", from a fear that the government could somehow figure out who they voted for, or that there might be a "freak election result" and PAP would no longer be in power (see Khalik \& Tham 2015). Singaporeans voted for the PAP 
because the PAP, over the years, has "stoke[d] this self-limiting and counter-productive fear", he claims (Chee 2015).

Chee is a prominent opposition party member in Singapore having joined Singapore politics in 1992. Over the years, he has been declared bankrupt after losing defamation suits brought about by former PAP prime ministers, and arrested and imprisoned over offenses related to public speaking and illegal assembly (Han 2012). Chee's story is as an example to many Singaporeans, a contributing factor to the feeling of fear that joining opposition parties might invite retaliation from the government (Ortmann 2010). Novelist Catherine Lim refers to the PAP government's history of "responding severely to any criticism of government style of competence" as creating a fear that "silence[s] existing dissident voices and discourage[s] potential ones", omnipresent enough to affect the everyday lives of Singaporeans and create self-censorship in their behavior (C. Lim 2007).

The PAP government have been generally cautious about what they have called the irresponsibility of a "free-for-all internet campaigning environment without rules" (British Broadcasting Corporation 2001). During the 2006 General Elections, the Media Development Authority, a statutory board of the Singapore government, put out a notice that individuals who use their websites and blogsites to "persistently propagate, promote or circulate political issues relating to Singapore", had to register as holders of political websites (Chia, Low \& Luo 2006). The government insisted that this was merely administrative and not "punitive in nature", a measure to ensure that individuals would not be able to "hide behind the anonymity afforded by the Internet in order to influence the electoral process" (Bhavani 2006). According to Balaji Sadasivan, a Senior Minister of State, individuals needed to realize that "they are still governed by the laws of the land [...] includ[ing] libel" (The Straits Times 2006). Opposition party members reacted strongly to the legislation, concerned that it will affect their campaign strategies and more importantly, shut down political discourse when voters fear breaking the law (Chia et al. 2006). Such subjugation of the media is not new nor unusual to Singaporeans (Seow 1998); with media laws that dictate the freedom of the press and protect the PAP's interests over the years, the PAP's ability to shut down contrasting views have led their regime to be described as authoritarian by political observers (Rodan 2004; Tan 2012). 


\subsection{RAPID MEDIATIZATION AND A CHANGING CLIMATE}

In 2011, however, amidst social pressure to "keep up with the times", the PAP government amended the Parliamentary Elections Act, cautiously lifting the total ban on online campaigning. Since then, Singapore politics have undergone a rapid mediatization, as a new political public sphere has emerged from the interaction between traditional print and broadcast media with new platforms of digital and social media. There has been an explosion in the number of websites focused on sociopolitical commentary and news in Singapore (Salleh 2015), and an increasing social media platform presence: Twitter and Facebook have grown into spaces for the dissemination of information about political rallies, and YouTube and other video streaming sites have provided the platform for election rallies to be edited and broadcast over the internet. For opposition parties, the easing of restrictions governing online content has opened up new platforms to rally for support. Their messages can now directly reach the public, unconstrained by the curation of government-controlled traditional media outlets. In fact, the proliferation of online coverage has also pressured the mainstream media to produce "more balanced" coverage, something that was seen as lacking in previous elections. In an online debate organized by nowdefunct political website Inconvenient Questions, Ramesh Subbaraman, a former senior reporter with state-owned media organization Mediacorp, revealed how television reporters in the past, for example, were instructed to "take close-up shots (so as not) to show [...] large crowds at certain rallies [...] [b]ut that is all gone today" (T. H. Tan 2015).

These new methods of circulation and recirculation of political messages have also lowered barriers to entry to participating in politics for many Singaporeans (Mydans 2011), a significant development when compared to the threat of regulation and arrest posed in the previous elections. The participatory structures present in the framework between politician and electorate are unique, especially when interactions play out in a virtual space like the internet. Here, I find it useful to refer to Erving Goffman's (1981) participant framework in interaction: as political messages circulate across digital domains, the recipients of the message (voters) are separated in space and time from the principal/animators of the message. Thus, these voters are not 'ratified listeners' in the traditional sense, due to their inability to participate discursively at the point when the message is produced. Ian Hutchby (2006) categorizes this particular participant role as "distributed recipient", much in the same vein as we might categorize audience members in a broadcast television show. The change in the Parliamentary Elections Act not only allowed for Singaporeans 
to enter the conversation without the threat of government oversight or regulation, but presented ways in which these distributed recipients could produce feedback (Chovanec \& Dynel 2015), or become principal-animators in their own right through Facebook, Twitter or comments on forums and blogs. The once-passive recipient role has shifted to an active one that is afforded production privileges, and it is in these new spaces where politicians, opposition or not, can be under closer scrutiny of the electorate. Thus, to understand Singapore's political climate is to make sense of the interdependencies between traditional and participatory media, political organizations, and Singaporean citizens, Singapore's form of “mediatized democracy” (Mazzoleni \& Schulz 1999).

\section{SINGLISH AND THE INDEXICAL MODEL}

Perhaps the primary question that backgrounds research on Singlish in Singapore, is how to define what it is and what it does for speakers. The body of work on Singlish is substantial, yet its linguistic status has confounded academic commentators. Recent structural work on Singlish focused on linguistic features often examines the variety's emblematic sentence-final particles (see Wee 2004; L. Lim 2007; and Hiramoto 2012 for examples) or tense, aspect, and modality markers (Bao 2005; Nomoto \& Lee 2012). For example, Bao Zhiming's 2005 work on the Singlish use of already in clause-final positions investigates what he sees as Chinese influence, concluding that its coding of aspectual meanings echoes that of the Chinese particle LE. Hiroki Nomoto and Nala Lee (2012) argue that the use of GOT in Singlish is neither a tense nor aspect marker, as previously classified, but rather a realis modality marker that codes temporality through the requirement of the factual status of situations at the time of utterance. While the value of structural studies cannot be understated, most of such work on Singlish identify specific iconic elements whose "Singlishness" will never be refuted.

It is not surprising, then, that much of the academic research on Singlish is social in approach. This research, influenced by newer sociolinguistic research paradigms (cf. Bucholtz \& Hall 2005), involves extensive studies on the role of Singlish as an ideological resource for identity construction, analyzing its use within a variety of political, economic, and cultural contexts (Alsagoff 2010). As a result, just in the past decade, the sociolinguistic body of research that models Singlish in relation to an overtly prestigious Singapore Standard English has been extensive and detailed (e.g., Alsagoff 2010, 2013; Wee 2011; Chua 2011; Leimgruber 2013). In these studies, the movements between the standard variety and Singlish are seen as fluid, dynamic 
achievements, as speakers negotiate different stances and identities in using and talking about Singlish. This approach implies that for many of these researchers, a code-switch from Singlish to English is an ideological one, and the overall effect of this mixing allows Singaporeans to construct equally dynamic intersubjectivities. Lubna Alsagoff's (2010) Cultural Orientation Model, for example, explores GLOCALIZATION as an explanation to the lack of any clear boundaries between the two languages. She focuses on the simultaneous global and local contextual pressures that speakers must negotiate as they interact, and while speakers do seem to orient to one variety or another as they produce speech, the overall effect is one of mix. The argument here is that this unbounded mixture between the two varieties is itself important to understanding the ideological tensions that speakers face.

Jakob Leimgruber (2012) has proposed that Singlish can be best described by an indexical model, drawing on the frameworks of indexical order (Silverstein 2003) and indexical field (Eckert 2008). In a variety like Singlish, where there is no "easily identifiable matrix language" (Leimgruber 2012:11), he argues that it is perhaps more productive to think of Singaporean discourse as elements (or features) associated with the multiple codes used in the region. By relegating the correlation between LANGUAGE VARIETY and LINGUISTIC FORM to a metapragmatic and possibly, metadiscursive level, we can then investigate the social meanings of Singlish tokens without taking away or assuming that speakers themselves are orienting to absolute "bounded entities" (Blommaert \& Rampton 2011) as they interact (Leimgruber 2012). I take Leimgruber's insightful work as the starting point of my inquiry into the process of enregisterment of Singlish. I argue that the legitimization of Singlish is produced through the more "authentic" (cf. Woolard 2016) authority, the Singaporean electorate.

\subsection{SOCIAL MEANINGS OF SINGLISH}

The concept of orders of indexicality, as proposed by Michael Silverstein in 2003, is interested in the process by which linguistic forms acquire social meaning; how INDEXICALITIES are born through social interaction. Leimgruber's work on Singlish, while useful in revealing the circularity of a variety-first approach (speakers, to be more Singaporean, use Singlish, therefore forms are Singlish are when speakers “do being Singaporean"), does not specifically address what social meanings are increasingly linked to Singlish tokens, or how the selection of what constitutes Singlish is done by speakers. If there is no "easily identifiable matrix" in Singlish, we perhaps need to turn our attention to the processes at the second order of indexicality, in which 
enregisterment of a variety can occur, and what features get stabilized in the process (Johnstone et al. 2006).

We first consider Singlish at its first order of indexicality. According to Silverstein, Nth-order indexicals are features whose accounts of their correlation with use are "scientific" (2003:205), a link that can be easily identified by cultural outsiders. In the case of Singlish features, we see this presented rather evidently in the indexical link between Singlish use and "Singaporean-ness": a "local"-ness that is distinctively different from a "global" orientation (Alsagoff 2010). Singlish is what is used by Singaporeans, what all Singaporeans know, and to use Singlish is to be Singaporean. At this level of indexicality, any conclusion on why Singaporeans use Singlish would therefore be analytically unproductive; it does not provide any further insight into where the boundaries of Singlish are with regards to its co-existence with standard Singapore English, that being one of the aims of researchers working on defining Singlish. This indexical phenomenon, then, becomes productive when it gains enough saliency to be "available for social work" (Johnstone et al. 2006:82), where the Nth-order correlation can give rise to a correlation at the level of $\mathrm{N}+1$. This $\mathrm{N}+1 \mathrm{TH}$-order indexicality is driven by ethno-pragmatic interpretations of $\mathrm{Nth}-\mathrm{level}$ indexicality, and is formed by ideologies surrounding who uses Singlish. It is at this level that my interest in Singlish lies. The following sections will investigate, in more detail, the processes in which Singlish tokens gain particular social meanings.

\subsection{HUMOR, POLITICAL RESISTANCE, AND NON-ELITENESS}

One of the earliest and most prominent examples of political satire occurred as a direct result of the 2006 debate on a new law that prohibited proselytizing on the internet. Many Singaporeans were confused by the ambiguity of the government's position: any online website that were found to "persistently propagate, promote or circulate political issues relating to Singapore" (Chia et al. 2006) were "political", and therefore, needed to be registered with the Media Development Authority of Singapore. To get around the legislation, two of Singapore's most prolific bloggers and podcasters, Lee Kin Mun (mrbrown) and Benjamin Lee (Mr Miyagi), started the "persistently non-political podcast" during the 2006 general elections as a way to report on election happenings using analogous, fictional stories that appealed to local knowledge. Unable to overtly "circulate political issues", they spoofed a particular incident where the PAP was seen to be haranguing an opposition party member for a lie he had told, analogizing it as an exchange between a hawker 
vendor selling BAK CHOR MEE, popular national dish of minced pork noodles, and his customer. A portion of the podcast is reproduced below:

(2) Customer: Uh.. wait wait, hang on. This has TUR KUA in it.

Wait, wait, hang on. This has pork liver in it.

Hawker: Yah lah, is got TUR KUA, liver one what.

Yes, (this dish usually) has pork liver.

Customer: But I said I didn't want TUR KUA.

Hawker No you didn't.

Customer: Yes I did.

$[\ldots][$ several lines redacted]

Hawker: No you didn't and I can prove it to you ah.

Customer: Very well, prove it!

Customer: The what?

Hawker: Nah, you see, you point to the MEE POK, then, you say dry. Then, you point to the chilli, then, you shake your head. You never say you don't want to have the TUR KUA!

Here, you see, you pointed to the flat noodles then you said dry noodles (not in soup). Then, you pointed to the chilli, then you shook your head. You never said you didn't want the pork liver!

The hawker vendor in the above example represents the PAP, and the customer the hapless opposition party member. This was a spoof of an incident where the PAP was seen to be continuously demanding an explanation from an opposition party member who had apologized for his mistake, inadvertently also making viral the Singlish phrase "sorry also must explain!". This event was generally interpreted by Singaporeans as an inconsequential and petty act by the ruling PAP, something further propagated by the release of this podcast.

This episode of the "persistently non-political podcast" went viral and was shared more than 100,000 times (Koh 2006) It propelled mrbrown to internet celebrity status, and gained enough attention that PAP Prime Minister Lee Hsien Loong, in his National Day Rally speech later that year, referenced the podcast in a bid to demonstrate his government's willingness to adapt to new approaches in reaching out to Singaporeans. The success of that podcast episode led mrbrown to produce more episodes focusing on politics in Singapore, some of them featuring the same hawker vendor and his customer. The show also released several free downloadable desktop wallpapers on its website, featuring an anthropomorphized "tur kua" character raising a fist in the air in anger (see Figure 2 below), together with a particularly popular phrase from the episode, "Why you say you tell me you dowan tur kua when you didn't say you dowan tur kua?" 'Why did you say (that) 
you told me (that) you didn't want pork liver when you didn't say (that) you didn't want pork liver?'

FIGURE 2. TUR KUA DESKTOP WALLPAPER AVAILABLE FOR DOWNLOAD ON MRBROWNSHOW.COM

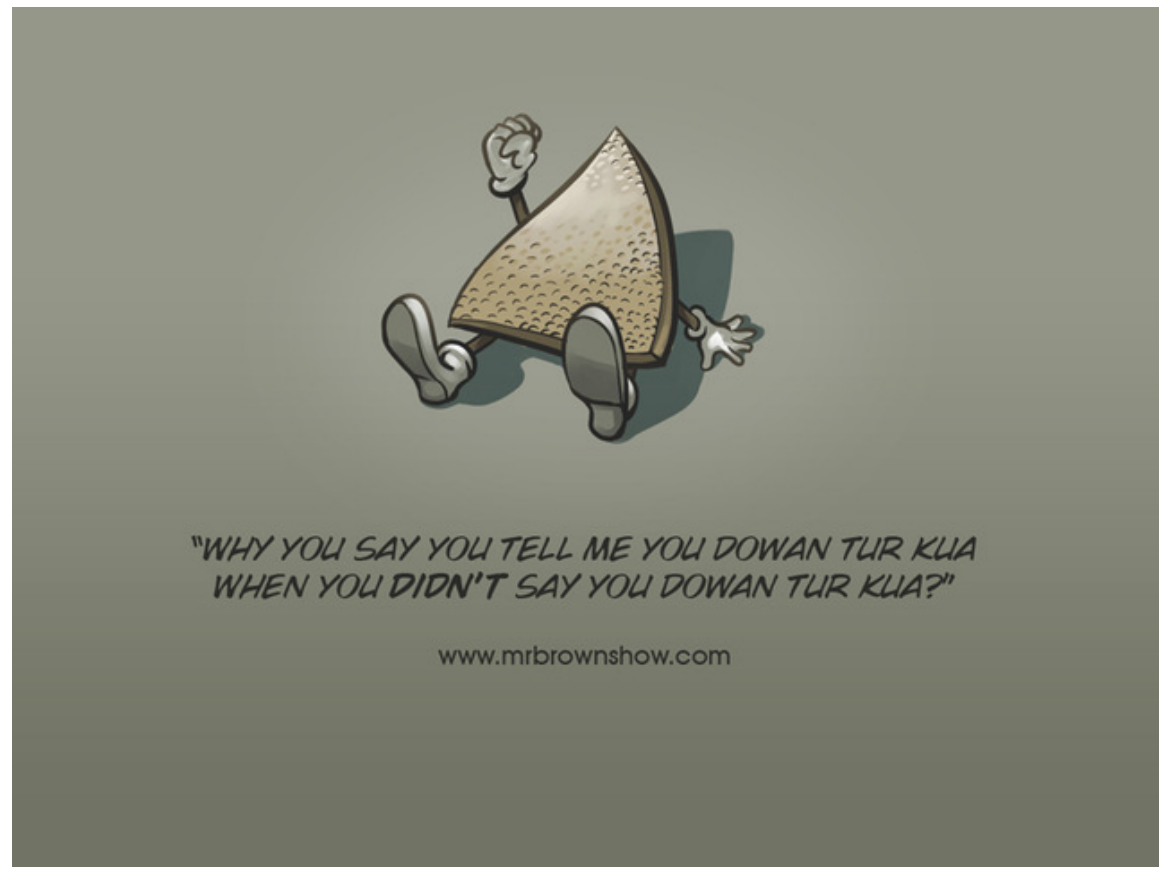

What is fascinating in this example is the how mrbrown and Mr Miyagi have exploited linguistic signs in one satirical podcast, and the specific forms that then get entextualized in new contexts like the desktop wallpaper. In the podcast episode, the original incident was taken from its political, "formal" context and supplanted in a distinctively local setting, the hawker center. The linguistic tokens used here also follows this backdrop, with the hawker vendor speaking in a local, non-standard register, notably different from the customer, who continues the conversation in a recognizably more "standard" variety. In the desktop wallpaper, the phrase that is seen as most salient, thus worthy of enshrining, is also an utterance made by the hawker vendor. As a form of ridicule, the podcast succeeded as one of the first examples of political resistance on the internet" it achieves both a very funny, native re-frame of the PAP's actions, as well as simultaneously mocks the draconian law against putting political content online. Most importantly, the linguistic signs employed here are "very Singaporean", which then opens up the potential for their categorization as Singlish. Ridicule here acts as a form of rebellion (Billig 2005), where humor can be found in both 1) the challenging of authority, as well as 2) in "breaking the codes of 
language", expected rules of communication when talking about politics (2005:207). By using very recognizable, local contexts, mrbrown and Mr Miyagi draw social boundaries of "us" versus "them", and bring Singaporeans who see themselves as non-elite and anti-establishment together through the mockery of the elite class.

\subsection{THE OPPOSITION POLITICIAN}

Opposition political parties, due to decades of suppression by the PAP, are a natural symbol of political resistance to most Singaporeans. The main focus when developing the brand of an opposition candidate has always been to present oneself as an alternative voice to an elite PAP who have been in power for so long, that they are out of touch with Singaporeans on the ground (The Workers' Party 2015). "Non-eliteness" and "anti-PAP" are second-order indexicalities that have been increasingly linked to non-standard features, and thus it is easy to see how they might be taken up as a resource in opposition politician speech. Recall at this point the example of "ownself check ownself" at the beginning of this paper. Pritam Singh cannot just give his entire speech in the local register. English, or standard Singapore English, is the language of the government and administration, the main medium of instruction in schools, and was crucial to Singapore's ability to participate in the global marketplace (Goh \& Gopinathan 2008). English language proficiency has always been seen as integral to the Singaporean brand, commodified and celebrated as skill (Heller 2010). Political candidates like Singh, in their speeches, need to be able to manage conventionalized expectations of using English, as it carries indexicalities of personal and academic success. When promoting the Worker's Party manifesto throughout the rest of his speech, Singh speaks entirely in English, the overtly prestigious language. At the point where he makes a strong criticism of the PAP, he asks the crowd, "Is this the future we want for Singapore or our children in the next fifty years?", inciting a shouted response "NO!". He then follows up with "Ownself check ownself!" If we take Singlish to be an indeterminate nebula of signs, then the question we should be asking is how, then, does "ownself get ownself" get enregistered as Singlish? The following section examines how the phrase acquires legitimacy at the $\mathrm{N}+1 \mathrm{TH}$ order of indexicality.

As mentioned, Singh deviates from a speech given almost completely in standard Singapore English. "Ownself check ownself” is not recognizable as English, yet this phrase is creative, never heard before in public settings, and (possibly) uncommon in day-to-day interaction, which makes it hard to categorize definitively as Singlish either. However, it is used in the context of "politically 
resisting", as a criticism of the ruling party, at a political rally held by the opposition. It incites laughter from the audience, an example of one more non-standard expressions used to mock authority. Singh, like mrbrown and Mr Miyagi before him, in a jocular moment, "broke[...] the codes of language" (Billig 2005), the political register expected of all Singaporeans running for office, again drawing the lines between "us" and "them", "elite" and "non-elite", "standard" and "non-standard" using a complex of multiple signs and exploiting their potential indexicalities. Most importantly, his words can be branded as Singlish in metapragmatic discourse surrounding his speaking abilities. An analysis of comments of online users further reveals how Singh's speech style is taken up by the broader public and linked to his identity as an opposition politician.

Although his speech was peppered with Singlish words, he came out as being intelligent, persuasive, and above all, eloquent. He has been hailed as the Obama of Singapore by some people on the Internet.

reddotrevolver, Online opinion article, 3 May $2011^{2}$

Having listened to his rally speeches, you are right PS will give the PAP dogs problems when he is elected. He is indeed an eloquent speaker. Sharp and witty too. user Golden Dragon, sammyboyforum ${ }^{3}$

Here, we see that Singh is hailed as eloquent, persuasive, and witty, and a potential formidable foe in parliament against the PAP. In the first comment, the commentator reddotrevolver highlights Singh's use of Singlish, glosses over its non-standard connotations (“ALTHOUGH his speech was peppered with Singlish words"), and characterizes him as a great speaker. For this online user, the presence of a non-standard variety in Singh's speech does not affect the way he "sounds" in a negative way, in fact according to user Golden Dragon, he is eloquent and witty. Note too that

${ }^{2}$ reddotrevolver (2011, May 3). Pritam Singh roasts the PAP.

Online: http://asiancorrespondent.com/2011/05/pritam-singhroasts-the-pap/; accessed October 4, 2015.

${ }^{3}$ Golden Dragon (2011, May 2). Must See: WP PRITAM SINGH Very Powerful Speech For Voters All Over Singapore. Sammyboyforum. [forum comment].

Online: http://www.sammyboy.com/archive/index.php/t91083.html?s=b76ac2ae0f4d2923d0bdfae091ff897b; accessed October 5, 2015. 
there is no further explanation of which words were Singlish, just a general sense that Singh's speech was "peppered" with them.

\subsection{LEGITIMIZING SINGLISH THROUGH ENTEXTUALIZATION}

Days after Singh's speech at the rally, known anti-establishment sociopolitical website All Singapore Stuff posted a video on their Facebook page (see Figure 3 below).

FIGURE 3. SCREENSHOT OF VIDEO POSTED ON FACEBOOK BY ALL SINGAPORE STUFF

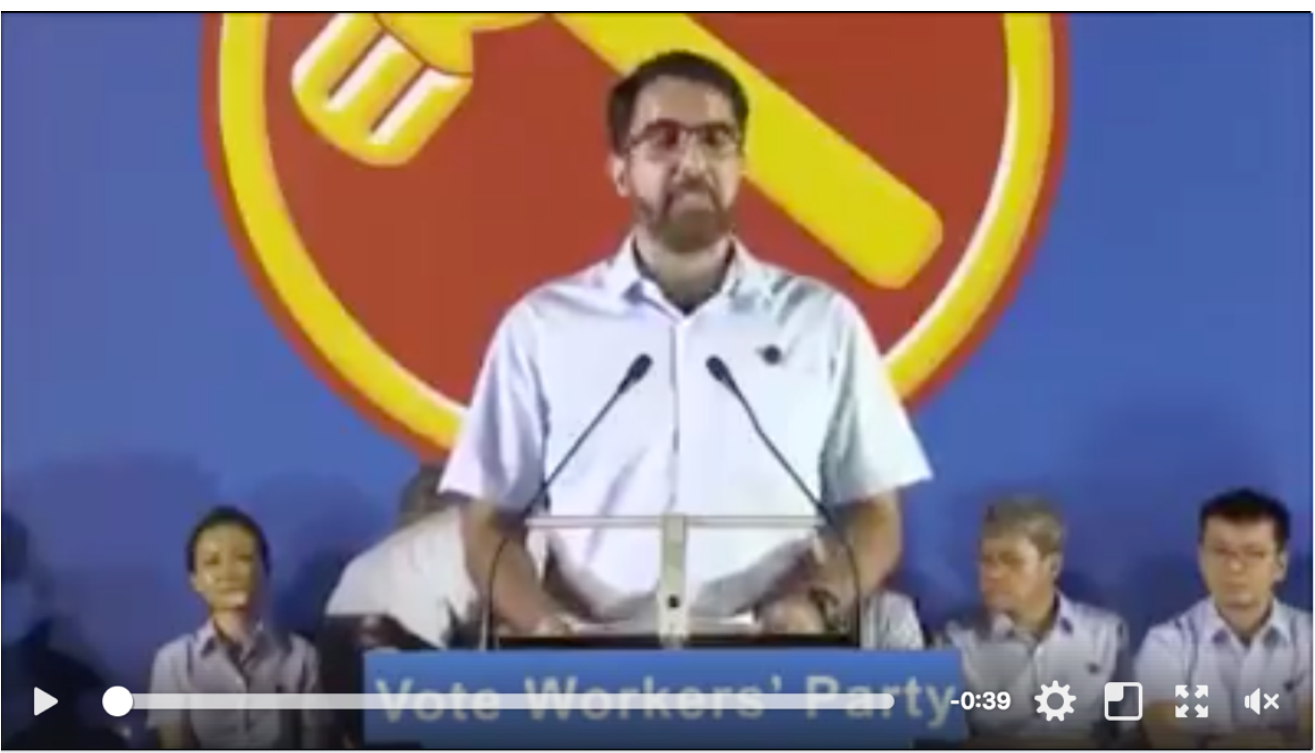

All Singapore Stuff

It Like Page

9 September $2015 \cdot$

Watch Lee Hsien Loong and Pritam Singh argue over OWNSELF CHECK OWNSELF :\#FUNNY \#OwnselfCheckOwnself \#GE2015 \#EastCoastWillFall

98k Views

It comes with the descriptor, "Watch Lee Hsien Loong and Pritam Singh argue over OWNSELF CHECK OWNSELF" and the hashtags \#FUNNY, \#OwnselfCheckOwnself, \#GE2015 and \#EastCoastWillFall. The 40-second video injects edited clips of Singh shouting "ownself check ownself” with that of PAP Prime Minister Lee's own rally speech segments, ultimately resulting in a video that mocks the PAP's position on "ownself" checking and balancing. This video has been viewed over 98,000 times and shared 1,472 times as of 1 July 2017 . We see the lines very clearly drawn between the opposition and the ruling politician, with abrupt jump cuts from one to the other, the WP pitted against the PAP. This was a clip meant to produce laughter (as evidenced 
by \#FUNNY) and chooses "ownself check ownself” as its main inspiration. Figure 4 shows other examples of the extextualizations of the phrase on Twitter, where the hashtag \#ownselfcheckownself started being used on Twitter in the days following Singh's speech.

FIGURE 4. SCREENSHOTS OF TWEETS THAT UTILIZE THE HASHTAG \#OWNSELFCHECKOWNSELF

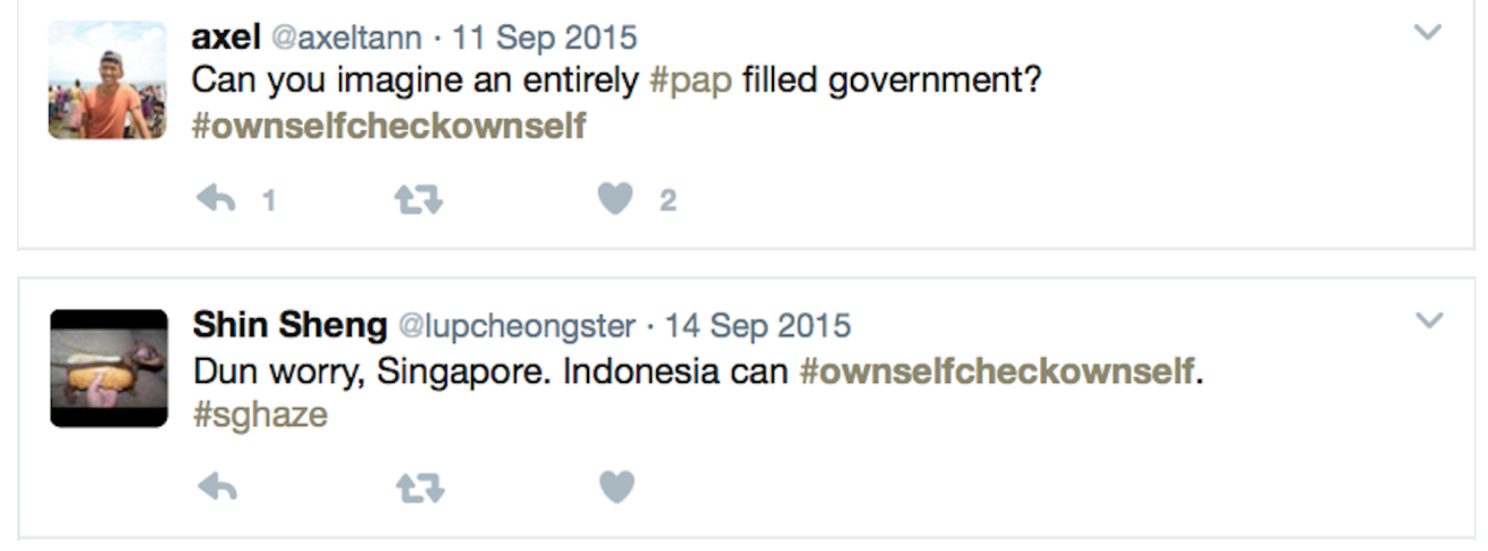

The first tweet by user axel (@axeltann) shows a thinly veiled criticism of the PAP, and the activation of the hashtag \#ownselfcheckownself marks user axel as a knowing member of the public against the PAP, someone who both recognizes "ownself check ownself" and wants to make a stand about the ruling party. In the second tweet, we see user Shin Sheng (@lupcheongster) using the hashtag in a completely different political context: referring to the 2015 Southeast Asian haze crisis, during which there was severe air pollution in neighboring Southeast Asian countries over a period of several months caused by illegally-created Indonesian forest fires which spread quickly in the dry season. With haze blanketing parts of Indonesia, Malaysia, and Singapore, the Singapore government's initial offers of help to combat the fires were declined by the Indonesian state, who stated that they have sufficient resources to deal with the crisis (A. Tan 2015). By posting "Don't worry Singapore, Indonesia can \#ownselfcheckownself", user Shin Sheng entextualizes "ownself check ownself" in a new context-of-use, further legitimizing the expression as a bona fide one that has pragmatic functions outside of its original context.

The tweets, shares, likes, and new uses of "ownself check ownself" in social media posts function as "identity statements expressing, pragmatically and metapragmatically, membership of some groups [...] not held together by high levels of awareness and knowledge of deeply shared values and functions, [...] but by loose bonds of shared, even if superficial interest" (Varis \& 
Blommaert 2015:35). By sharing and liking the post, or activating a hashtag, groups are brought together on demand, as individual users select their participation, indicating their recognition of the original context-of-use and then showing appreciation for its adaptation into a different modality. Humor is used in these ways online to bring groups together, not only because they think something is funny, but because what is funny is only funny if you have similar viewpoints about the PAP government. The affordances of these platforms allow an otherwise-invisible audience to rise up against a perceived more-powerful group, and the opening up of the internet has given the Singapore electorate spaces they previously never had to exercise judgment on their government, through "local" resources like Singlish.

In this process, we can also identify another what the Singaporean electorate find is particularly worthy-of-comment. "Ownself check ownself" is what is ruminated on (cf. Silverstein 2011), over and over again. Online commenters recognize the semiotic productivity of the phrase, and in their entextualization of it in newer contexts. They draw their own boundaries around language through the way they discuss the expression in their own posts, legitimizing "ownself check ownself" as an emblematic expression of Singlish. Literary critic Gwee Li Sui, in a May 2016 opinion piece about politics and Singlish in the international edition of the New York Times, pointed out that "even politicians and officials are using it", and specifically identifies Singh's "ownself check ownself" at the Workers' Party rally as an instance of Singlish use. The expression is a new, creative, and now-public sign that has been increasingly fossilized through each new metapragmatic re-use and entextualization. It BECOMES Singlish, as it accumulates citations through the codifying of resistance against the PAP elite.

\section{DISCUSSION AND CONCLUSION}

In the short paper above, I have outlined, in as much detail as I can given the limitations on space, the processes through which Singlish terms are enregistered as part of a language variety. The enregisterment process, as linguistic anthropologists have suggested across multiple publications, is highly ideological. I have illustrated how this process depends on the ways that subjects experience their sociopolitical environment. Singlish, as a language, undergoes constant shifts, and this paper hopes to provide some clarity into these processes of enregisterment, focusing on the instantiations of speaker metapragmatic use which can lead to the emergence of $\mathrm{N}+1 \mathrm{TH}$ orders of indexicality. The shifting interrelationships between traditional and new media, political 
actors and political observers has shown us how language can change, both reacting or being reacted to, as political agents conceptualize its ideological boundaries. Lastly, Johnstone et al. (2006) reminds us that orders of indexicality are in dialectical relationships with each other, and thus we see why Singlish can both be the resource and outcome of ongoing Singlish enregisterment processes. Second-order indexicalities (non-eliteness, political resistance through humor) can in turn inform first-order realities, and affect what linguistic features can picked up as Singlish as Singaporeans become more and more aware of the value of Singlish as an indicator of their "groupness".

The fight to gain social power by a historically silenced electorate will thus almost definitely involve symbols of localness and non-eliteness, and Singlish, with each citation, iconizes more and more to perform that duty of resisting the powerful. However, we see that these forms of resistance only showing up in instances of rebellious humor, of satire and parody. Singh, who as an opposition politician embodies political rebellion in Singapore, can only pick at specific moments in his speeches to use Singlish. He, together with the electorate, is constrained by societal expectations of what language is appropriate for which context. The change in attitudes towards Singlish, however, cannot be ignored, and it is in the political realm where we see it gaining the most traction in public settings. We cannot forget, however, to be skeptical of such developments. Progressive change from past practices might look like a step in the right direction, yet attention needs to be paid to what current work they are achieving. The almost military precision with which such humor is done, constrained into very specific settings, is the current domain of Singlish. According to Billig (2005), rebellious humor does not necessarily have rebellious effects, and as speakers reveal themselves as "captive" to the demands of having to incorporate humor as they make a stance against the PAP, the overall effect could be one that strengthens instead of subverting power. Singlish becomes synonymous with humor, with non-eliteness, and the language is further delegitimized as a variety in relation to English. In a similar vein, the PAP is increasingly associated with English, and benefits from its indexical links to global success and professionalism. Further investigation how political actors navigate the Singlish-English indexical field needs to be done to uncover the dynamics of language and power in the Singapore context. This would also provide new insight into the role Singlish plays in Singaporean society, and in the construction of Singaporean identities. 


\section{REFERENCES}

Agence France-Presse. 2001. PAP synonymous with Singapore government. November 4, 2001. Retrieved May 8, 2014 from http://www.singapore-window.org/sw01/011104a2.htm

Agha, Asif. 2005. Voice, footing, enregisterment. Journal of Linguistic Anthropology 15(1).3859.

Alsagoff, Lubna. 2010. English in Singapore: culture, capital and identity in linguistic variation. World Englishes, 29(3).336-348. Retrieved 2016-04-19, from http://onlinelibrary.wiley.com/doi/10.1111/ j.1467-971X.2010.01658.x/abstract

Alsagoff, Lubna. 2013. Singlish in hybridity: The dialogic of outer-circle teacher identities. The Global-Local Interface and Hybridity: Exploring Language and Identity, ed. by Rani Rubdy and Lubna Alsagoff, 265-281. Multilingual Matters | Channel View Publications.

Bao, Zhiming. 2005. The aspectual system of Singapore English and the systemic substratist explanation. Journal of Linguistics 41(2).237-267.

Bhavani, K. 2006, April 20. Election advertising is prohibited on the Net. The Straits Times forum. Retrieved from https://www.mci.gov.sg/pressroom/news-andstories/pressroom/2008/1/election-advertising-is-prohibited-on-the-net?page $=159$

Billig, Michael. 2005. Laughter and ridicule: towards a social critique of laughter. London; Thousand Oaks: Sage.

Blommaert, Jan and Rampton, Ben. 2011. Superdiversity. Diversities, 13(2).4-18, from http://www.mmg.mpg.de/fileadmin/ user_upload/Subsites/Diversities/Journals_2011/ 2011_13-02_gesamt web.pdf

Bourdieu, Pierre. 1977. The economics of linguistic exchanges. Social Science Information, 16.645-668. doi: 10.1177/ 053901847701600601

Bucholtz, Mary and Hall, Kira. 2005. Identity and interaction: A sociocultural linguistic approach. Discourse Studies 7(4-5).584-614.

British Broadcasting Corporation. 2001, August 14. Singapore net law dismays opposition. $B B C$ News. Retrieved from http://news.bbc.co.uk/2/hi/asia-pacific/1490425.stm

Chee, Soon Juan. 2015. Fear and our future. cheesoonjuan.com. Retrieved from http://www.cheesoonjuan.com/ home/fear-and-our-future

Chia, Sue-ann; Low, Aaron; and Luo, Serene. 2006, April 5. Opposition parties slam podcast ban rule. The Straits Times. Retrieved from http://www.international.ucla.edu/asc/article/42107 
Chovanec, Jan and Dynel, Marta. 2015. Participation in Public and Social Media Interactions. John Benjamins Publishing Company.

Chua, Beng Huat. 1995. Communitarian Ideology and Democracy in Singapore. Routledge. Chua, Catherine Siew Kheng. 2011. Singapore's E(Si)nglish-knowing bilingualism. Current Issues in Language Planning 12(2).125-145.

Cochrane, Joe. 2015. Singapore vote will test long ruling party's grip on power. The New York Times. Retrieved from https://www.nytimes.com/2015/09/10/world/asia/singapore-vote-willtest-long-ruling-partys-grip-on-power.html

Eckert, Penelope. 2008. Variation and the indexical field. Journal of Sociolinguistics, 12(4).453476.

Gal, Susan. 1989. Language and political economy. Annual Review of Anthropology, 18(1).345367.

Goffman, Erving. 1981. Forms of talk. University of Pennsylvania Press.

Goh, C. B., and Gopinathan, S. (2015). The development of education in Singapore since 1965. Toward a better future: Education and training for economic development in Singapore since 1965, ed. by Lee Sing Kong, Tan Jee Peng, Birger Fredriksen, and Goh Chor Boon, 12-38. Washington, DC: The World Bank Publications and the National Institute of Education (NIE) at Nanyang Technological University.

Hall, Kira and Nilep, Chad. 2015. Code-switching, globalization, and identity. Handbook of Discourse Analysis, ed. by Deborah Tannen, Heidi E. Hamilton and Deborah Schiffrin, 597619. Malden, MA: Wiley-Blackwell.

Han, Kirsten. 2012. Democratically speaking: Chee Soon Juan promotes nonviolent action in Singapore. wagingnonviolence.org. Retrieved from https://wagingnonviolence.org/feature/democratically-speaking-chee-soon-juan -promotesnonviolent-action-in-singapore/

Heller, Monica. 2010. The Commodification of Language. Annual Review of Anthropology, 39(1).101-114. Retrieved from https://doi.org/10.1146/annurev.anthro.012809.104951 doi: 10.1146/annurev.anthro.012809.104951

Hiramoto, Mie. 2012. Pragmatics of the sentence-final uses of can in Colloquial Singapore English. Journal of Pragmatics 44(6).890-906. 
Hutchby, Ian. 2006. Media talk: Conversation Analysis and the Study of Broadcasting. Glasgow: Open University Press.

Johnstone, Barbara; Andrus, Jennifer; and Danielson, Andrew. E. 2006. Mobility, Indexicality, and the Enregisterment of "Pittsburghese". Journal of English Linguistics, 34(2).77-104.

Khalik, Salma and Tham, Yuen-C. 2015. No guarantee PAP will be in government after polls: Khaw Boon Wan. The Straits Times. Retrieved from http://www.straitstimes.com/politics/noguarantee-pap-will-be-in-government-after-polls-khaw-boon-wan

Koh, Leslie. 2006. Net spoof too funny for serious politics? The Straits Times. Retrieved from http://www.international.ucla.edu/asc/article/47020

Lee, Kuan Yew. 2012. From Third World to First: The Singapore Story, 1965-2000. Vol. 2. Marshall Cavendish International Asia Pte Ltd.

Leimgruber, Jakob. 2012. Singapore English: an indexical approach. World Englishes, 31(1).114.

Leimgruber, Jakob. 2013. Singapore English: Structure, variation, and usage. Cambridge University Press. (Studies in English Language Series).

Leimgruber, Jakob. 2014. Singlish as defined by young educated Chinese Singaporeans. International Journal of the Sociology of Language. Retrieved from https://www.degruyter.com/view/j/ijsl.2014.2014 .issue-230/ijsl-2014-0026/ijsl-20140026.xml doi: 10.1515/ijsl-2014-0026

Lim, Catherine. 2007, October 29. SG Daily Special: An Open Letter To The Prime Minister By Catherine Lim. Singaporedaily.net. Retrieved from http://singaporedaily.net/2007/10/29/sgdaily-special-an-open-letter-to-the-prime-minister-by-catherine-lim/

Lim, Lisa. 2007. Mergers and acquisitions: on the ages and origins of Singapore English particles. World Englishes 26(4).446-473.

Mazzoleni, Gianpietro and Schulz, Winfried. 1999. "Mediatization" of Politics: A Challenge for Democracy? Political Communication, 16(3).247-261. Retrieved from http://www.tandfonline.com/doi/abs/10 .1080/105846099198613 doi: $10.1080 / 105846099198613$

Mutalib, Hussin. 2002. Constitutional-electoral reforms and politics in Singapore. Legislative Studies Quarterly, 27(4).659-672. 
Mydans, Seth. 2011. Opposition makes inroads in Singapore. The New York Times. Retrieved from http://www.nytimes.com/2011/05/08/world/asia/08singapore.html

Nomoto, Hiroshi and Lee, Nala H. 2012. Realis, factuality and derived-level statives: perspectives from the analysis of Singlish got. Building a bridge between linguistic communities of the Old and the New World: Current research in tense, aspect, mood and modality 25.219-239.

Ortmann, Stephan. (2010). Politics and change in Singapore and Hong Kong: Containing contention. Routledge.

Ortmann, Stephan. 2011. Singapore: Authoritarian but newly competitive. Journal of Democracy, 22(4).153-164. Retrieved from https://muse.jhu.edu/article/454067/summary

Philomin, Laura E. 2015. Check and balance a seductive lie: ESM Goh. TODAYOnline. Retrieved from http://www.todayonline.com/singapore/check-and-balance-seductive-lie-esmgoh

Risse, Mathias. 2014. From Third World to First what's next? Singapore's obligations to the rest of the world from a human rights perspective. HKS Working Paper No. RWP14007.1-25. Retrieved from https://ssrn.com/abstract $=2410434$

Rodan, Garry. 2004. Transparency and authoritarian rule in Southeast Asia: Singapore and Malaysia. Routledge.

Salleh, Nur Asyiqin Mohamad. 2015. Political websites creating a buzz in Singapore. The Straits Times. Retrieved from http://www.straitstimes.com/singapore/political-websites-creating-abuzz-in-singapore.

Seow, Francis T. 1998. The Media Enthralled: Singapore Revisited. Lynne Rienner Publishers.

Silverstein, Michael. 2003. Indexical order and the dialectics of sociolinguistic life. Language and communication, 23(3).193-229.

Silverstein, Michael. 2011. Presidential Ethno-blooperology: Performance Misfires in the Business of" Message"-ing. Anthropological Quarterly, 84(1).165-186. Retrieved from https://muse.jhu.edu/article/417394/summary

Silverstein, Michael and Urban, Greg. 1996. Natural Histories of Discourse. University of Chicago Press. 
Tan, Audrey. 2015. Jakarta again declines Singapore's help to fight haze. The Straits Times. Retrieved from http://www.straitstimes.com/singapore/environment/jakarta-again-declinessingapores-help-to-fight-haze

Tan, Kenneth P. 2012. The ideology of pragmatism: Neo-liberal globalisation and political authoritarianism in Singapore. Journal of Contemporary Asia 42(1).67-92.

Tan, Netina. 2014. The 2011 general and presidential elections in Singapore. Electoral Studies $35.374-378$.

Tan, Tarn How. 2015. GE 2015: media coverage more "balanced", say ex-insiders. The Online Citizen. Retrieved from https://www.theonlinecitizen.com/2015/09/11/ge-2015-mediacoverage-more-balanced-say-ex-insiders/

The Straits Times. 2006, April 4. Political podcasts, videocasts not allowed during election. The Straits Times. Retrieved from http://international.ucla.edu/institute/article/42036

The Worker's Party. 2015. Manifesto 2015: Enpowering Your Future. Worker's Party website. Retrieved from http:/www.wp.sg/manifesto/

Varis, Piia and Blommaert, Jan. 2015. Conviviality and collectives on social media: Virality, memes, and new social structures. Multilingual Margins 2(1).31-45.

Wee, Lionel. 2004. Reduplication and discourse particles. Singapore English: A grammatical description, ed. by Lisa Lim, 105-126. Amsterdam/Philadelphia: John Benjamins.

Wee, Lionel. 2011. Metadiscursive convergence in the Singlish debate. Language and Communication 31(1).75-85.

Woolard, Kathryn A. 2016. Singular and Plural: Ideologies of Linguistic Authority in 21st Century Catalonia. Oxford Studies in Anthropology of Language. Oxford University Press. 